\title{
Sivil Havacılık Sektöründe Büyük Veri Teknolojisinin Kullanımı ve Getireceği Yeni Fırsatlar
}

DOI: $10.26466 /$ opus.936145

\author{
Erdal Dursun* \\ * Dr.Öğr.Üyesi, Nişantaşı Üniversitesi, Sivil Havacılık Yüksekokulu, İstanbul/Türkiye \\ E-Posta: erdal.dursun@nisantasi.edu.tr O ORCID: 0000-0002-6255-1380
}

\section{Öz}

Sivil havacıllı sektörü teknolojik altyapısı sayesinde çok büyük miktarda veri üretme kapasitesine sahiptir. Büyük veri teknolojisi sayesinde sivil havactlı sektörü, bu muazzam büyüklükteki veri rezervini kullanarak iş süreçlerini yenileyebilecektir. Örneğin büyük veri teknolojisine dayalı olarak çeşitli tahmin algoritmaları veya derin öğrenme yöntemleri kullanılarak uçuş risklerini azaltmak, pazardaki değişimleri tahmin etmek, maliyetleri azaltmak, uçuş operasyonlarını ve bakım-onarım faaliyetlerini planlamak daha kolay hale gelecektir. Tüm dünyayı etkileyen COVIT-19 pandemisi döneminde seyahat kısıtlamaları sebebiyle havayolları şirketlerinin neredeyse tamamı, eşi görülmemiş bir mali krizle karşı karşıya kalmıştır. Büyük veri teknolojisi yoluyla elde edilebilecek dinamik veri analizleri sayesinde, havayolları küresel ve ülke bazlı talepleri karşılayabilmek için değişen pandemi şartlarını da dikkate alınarak en uygun uçuş operasyonların planlamak mümkündür. Çalışmada büyük veri teknolojisinin sivil havacılık sektöründe kullanım alanları, sektörde faaliyet gösteren firmalara sağlayabileceği firsatlar örnek uygulamalar ve süreç tanımlamalar yoluyla detaylı bir şekilde açıklanmıştır. Bu çalışmanın sektörde konu ile ilgili farkındalık yaratması ve bundan sonra yapılacak bilimsel çalışmalara katkı sağlaması beklenmektedir.

Anahtar Kelimeler: Sivil Havacllk, Büyük Veri Teknolojisi, Pandemi. 


\title{
Use of Big Data Technology and Oncoming New Opportunities in the Civil Aviation Sector
}

\begin{abstract}
By means of its technological infrastructure, the civil aviation sector has the capacity to generate a huge amount of data. Thanks to big data technology, the civil aviation industry will be able to refresh business processes using this enormous data reserve. For instance, using various prediction algorithms or deep learning methods based on big data technology, it will be easier to reduce flight risks, predict changes in the market, reduce costs, plan flight operations and maintain and repair activities. During the COVID19 pandemic, which affected the whole world, almost all airline companies faced an unprecedented financial crisis due to travel restrictions. In virtue of the dynamic data analysis that can be obtained through big data technology, it is possible to plan the most appropriate flight operations by taking into account the changing pandemic conditions in order to meet the global and country-based demands of airlines. During the analysis, sample implementations and method concepts describe the use of big data technologies in civil aviation and the possibilities it can bring to the companies in the field. This research should increase knowledge of the field and lead to further science studies.
\end{abstract}

Keywords: Civil Aviation, Big Data Technology, Pandemic. 


\section{Giriş}

Sivil havacılık sektöründe son elli yılda yaşanan teknolojik gelişmeler paralelinde gelen talep patlaması güvenliğin ön planda olduğu sektörde daha efektif yönetsel modellere ihtiyacı ön plana çıkarmıştır. Günümüzde sivil havacılık sektörünü tanımlayacak en önemli kavramlar yoğun rekabet ve düşük kârlılık oranlarıdır. Bu durumun en temel sebebi, sektörde kullanılan yüksek düzeydeki teknolojik altyapı bu ihtiyaçlar doğrultusunda ortaya çıkan büyük sabit sermaye yatırımlarıdır. Ayrıca sektörde büyük havayolu şirketlerinin oluşturduğu eksik rekabet ortamı, aşırı devlet sübvansiyonları, mevsimsel dalgalanmalar ve son dönemde yaşanan COVID-19 Pandemisi sektörde büyük sorunlar oluşturmuştur. Sektörde iyileşmeyi sağlamak amacıyla yeni arayışlar ortaya çıkmıştır. Büyük veri teknolojisinin sektörde kullanılmasına yönelik yapılan çalışmalar bu arayışların başında gelmektedir.

Büyük veri teknolojisi, bir bilgisayarda analiz edilebilen ve daha sonra kalıpları veya eğilimleri ortaya çıarılabilen son derece büyük bir veri kümesi olarak tanımlanmaktadır. Tanımdan da anlaşılacağı gibi büyük veri teknolojisi, sektörde oluşan tüm verileri biriktiren ve ihtiyaçlar doğrultusunda analiz edilebilen hale dönüştüren dinamik bir veri kümesidir. Sivil havacılık sektörü teknolojik altyapısı itibariyle en çok verinin üretildiği sektörlerden biridir.

Sivil havacılık sektöründe, uçuş öncesinde, uçuş sırasında ve uçuş sonrasında yapılan işlemlerden dolayı günlük olarak çok büyük miktarda veri ortaya çıkar ve kaydedilir. Örneğin günümüzde ortalama bir sivil uçuşta toplamda 1.000 Gigabyte civarında veri ortaya çımaktadır. Bu verilerin faydalı yönetsel bilgilere dönüştürülmesi için düzenli şekilde biriktirilmesi ve işlenmesi gerekmektedir. Bu amaçlar için, havayolları şirketleri büyük veri teknolojisini kullanmaktadır. Bu teknoloji bir insanın yapamayacağı birçok şeyi yapmamıza olanak sağlamaktadır. Kullanılan bilgisayar algoritmaları sayesinde büyük miktardaki veriler hızla işlenir ve muhtemel analizlerde kullanılmak üzere depolanır. Analizler, havayolu şirketlerinin iş süreçlerini optimize etmenize olanak tanır. Örneğin büyük veri teknolojisi ile, her müşteri hakkında bilgiler sağlanır, bu da havayolunun yolcuya bireysel bir yaklaşım bulmasına ve markaya 
olan müşteri sadakatini artıran hedefli pazarlama kampanyaları yürütmesine olanak tanır. Bunun yanında uçuş güvenliğini arttırmaya yönelik gerçek zamanlı hava durumu bilgilerini almaya veya gelecekte oluşabilecek uçak arızalarını tahmin etmeye yönelik modeller oluşturulmasına yardımcı olabilmektedir (Odarchenko vd., 2019, s.437).

Özetle büyük veri teknolojisi sivil havacılık sektöründe müşteri memnuniyeti, maliyet yönetimi, bütçe yönetimi, pazarlama yönetimi, filo yönetimi, bakım-onarım yönetimi ve risk yönetimi gibi konularda işletmelere daha efektif çözümler sunabilmektedir.

Çalışmanın amacl, büyük veri teknolojisini ve sivil havacilık sektöründe kullanım alanlarını örnek uygulamalar yoluyla açıklamaktır. Ayrıca büyük veri teknolojisinin sektörde faaliyet gösteren firmalara sağlayabileceği yeni fırsatları tespit etmek ve konu ile ilgili sektörde bir farkındalık yaratılması hedeflenmektedir.

\section{Büyük Veri Teknolojisi}

Tarih boyunca bilgi üretildi. Fakat büyük veri teknolojisi, çok büyük miktarlarda verinin toplanmasını, depolanmasını ve analiz edilmesini mümkün kıldı. Büyük veri, büyük miktarda veri kümesini ifade eder. Başka bir deyişle, büyük veri, sorumlu olabilecek veya olmayabilecek çeşitli kaynaklar tarafından yüksek hızda üretilen büyük hacimli verileri ifade eder. Bu verilerin işlenmesi ile, sınırlı veriler kullanılarak oluşturulması mümkün olmayan modeller, ilişkiler ve içgörüler elde edilir hale gelmiştir. Dünyanın önde gelen şirketleri artık daha iyi, daha akıllı, gerçek zamanlı kararlar vermek için büyük veri teknolojisini yaygın olarak kullanarak, rakiplerine göre avantaj sağlamaya başlamıştır (Sumathi vd., 2017, s.129).

Aslında özellikle büyük şirketler veri tabanlarını, sorgulamaları ve bunlara bağlı analizleri çok uzun zamandır tüm yönetsel faaliyetlerinde kullanmaktaydı. Fakat teknolojinin ilerlemesi ve özellikle internetin gelişmesiyle birlikte milyarlarca veri oluşmaya başladı. Sosyal medya paylaşımları, mobil cihazlardaki uygulamalar, web sayfalarında bırakılar loğlar ve nesnelerin interneti sayesinde oluşan sensör verileri gibi birçok bilimsel ve bilimsel olmayan veri bir araya gelmeye başladı. Aslında bu durum, hayal bile edemeyeceğimiz bir veri ekosistemini ortaya çıardı. 
İşte tam olarak büyük veri teknolojisi dediğimiz ekosistem aslında sadece verinin büyüklüğü değil; verinin toplanması, analiz edilmesi, saklanması yani veriden bir değer kazanılmasına olanak sağlamıştır (Kılıç, 2018, s. 1).

Büyük veri kavramı genellikle üç biçimde karşımıza çıkmaktadır (https://techvidvan.com/tutorials/big-data-complete-guide/):

1. Yapılandırılmış Veriler: Sabit bir biçimde saklanabilen, işlenebilen ve erişilebilen veriler olarak tanımlanır. Yapılandırılmış verilerin sabit bir şeması vardır ve bu nedenle kolayca işlenebilir. Örnek olarak İlişkisel Veri Tabanı Yönetim Sistemleri(RDBMS)'nde depolanan veriler verilebilir.

2. Yarı Yapılandırılmış Veriler: RDBMS'de tablo tanımı gibi herhangi bir resmi yapıya sahip olmayan verilerdir. Ancak anlamsal öğeleri ayırmak için işaretler ve etiketler gibi bazı organizasyonel özelliklere sahiptir. Bu durum analizi kolaylaştırır. Örnek olarak Genişletilebilir İşaretleme Dili(XML) dosyaları veya JavaScript Nesne Gösterimi(JSON) belgeleri verilebilir.

3. Yapılandırılmamış Veriler: Bilinmeyen biçimi veya yapısı vardır ve RDBMS'de depolanamaz. Yapılandırılmamış verileri yapılandırılmış bir biçime dönüştürülene kadar analiz edemeyiz. Kuruluşlar tarafından üretilen verilerin yüzde 80'i yapılandırılmamış verilerdir. Örneğin her türlü metin dosyaları, ses, video, resimler vb. multimedya içerikleri.

İşletmenin elindeki her veri büyük verimidir? Mevcut verilerinizin büyük veri teknolojisine dahil olabilmesi için aşağıda $5 \mathrm{~V}$ kuralı olarak tanımlanan 5 bileşenden en az birine sahip olması gerekmektedir (Aktan, 2018, s.4-5):

1. Hacim: Her gün üretilen veri miktarını ifade eder. Veri hacmi, belirli verileri büyük veri olarak kabul edip etmemeye karar verir. Dolayısıyla, "Hacim", bir veriyi büyük veri olarak kabul etmemiz için önemli bir şarttır.

2. Hız: Farklı kaynakların her gün büyük veri ürettiği hızı ifade eder. Bu veri akışı sürekli ve büyüktür. Örneğin sosyal medya platformlarında kullanıcı sayısının veya paylaşım sayısının her gün hızlı bir biçimde durmadan artmasi.

3. Çeşitlilik: Heterojen kaynaklar tarafından üretilen farklı veri biçimlerini ifade eder. Yapılandırılmış, yapılandırılmamış veya 
yarı yapılandırılmış olabilir. Daha önce verileri genelde excel veya veri tabanlarından tablolar halinde alıyorduk. Ancak günümüzde veriler resim, ses, video, PDF gibi farklı birçok şekilde karşımıza gelebilmektedir.

4. Doğruluk: Veri tutarsızlığı ve eksikliğinden kaynaklanan verilerin belirsizliğini ifade eder. Büyük Veri ile uğraşırken, kuruluşlar veri belirsizliğini göz önünde bulundurmalıdır.

5. Değer: Bilgisiz veriler anlamsızdır. Büyük veri, biz onu değere dönüştürene kadar işe yaramaz. Sadece büyük verileri toplamak ve depolamak yetmez. Toplanan veriler analiz edilip faydalı bir çıktı elde edilinceye kadar değersizdir.

İşletmelerde karar süreçlerinde büyük veri teknolojisinin kullanılabilmesi için verileri analiz edecek ve faydalı olanlarını ayrıştıracak bir sisteme ihtiyaç vardır. Literatürde büyük veri mimarisi olarak isimlendirilen bu sistem Şekil 1'de tanımlanmıştır.

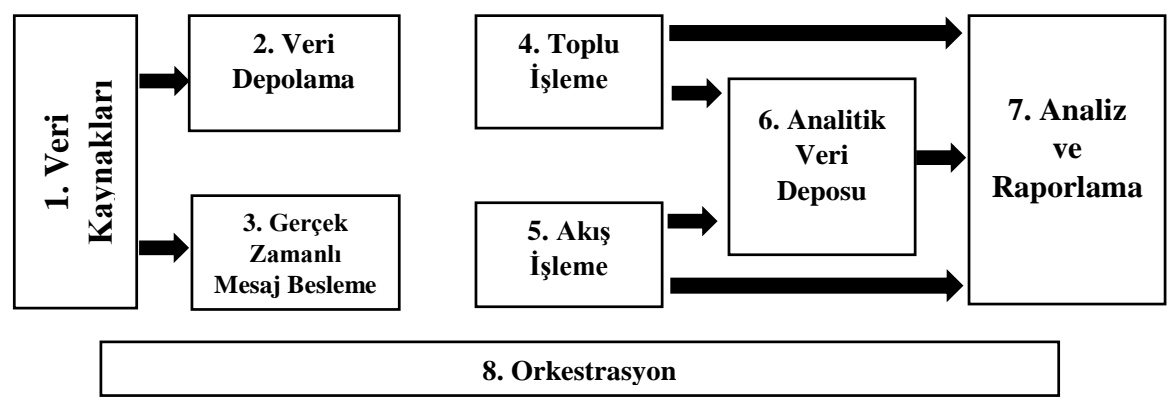

Şekil 1. Büyük Veri Mimarisi (Kaynak: https://techvidvan.com/tutorials/bigdata-aviation/)

Veri Kaynakları: Büyük veri mimarisini yönetir ve büyük veri hattının başlangıç noktasıdır. Veriler, ilişkisel veri tabanları, sensörler, şirket sunucuları, IoT cihazları, Windows günlükleri gibi uygulamalardan oluşturulan statik dosyalar, üçüncü taraf veri sağlayıcıları gibi birden çok kaynaktan gelir. Bu veriler toplu veri veya gerçek zamanlı veriler olabilir. Büyük veri mimarisi, bu büyük miktardaki veriyi işleyecek şekilde tasarlanmıştır. 
Veri Depolama: Büyük veri için alıcı uçtur. Veri depolama, birden çok veri kaynağından çeşitli biçimlerde veri alır ve bunları depolar.

Gerçek Zamanlı Mesaj Besleme: Büyük veri mimarisinde, akış işleme tüketicileri tarafından tüketilen gerçek zamanlı verileri yakalayan ve depolayan bir mekanizma oluşturmadır. Bu, mesaj kutusuna gelen yeni mesajlar olarak tanımlanabilir.

Toplu İşleme: Mimari, verileri filtrelemek, toplamak ve işlemek için çok büyük boyutta bir toplu işleme sistemine ihtiyaç duyar. Toplu işleme için en yaygın kullanılan çözüm Apache Hadoop'tur.

Akış İşleme: Gerçek zamanlı mesajların anlık olarak işlenmesidir.

Analitik Veri Deposu: Verileri işledikten sonra, tüm veri setinin analizini gerçekleştirebilmemiz için gerekli verileri tek bir yere getirmemiz gerekir. Analitik veri deposu, tüm süreç verilerimizi tek bir yerde depolaması ve analizi kapsamlı hale getirmesi açısından önemlidir. İhtiyaçlarımıza bağlı olarak ilişkisel bir veri tabanı veya bulut tabanlı bir veri ambarı olabilir.

Analiz ve Raporlama: Çeşitli veri kaynaklarından veri alıp işledikten sonra, verileri analiz etmek için bir araca ihtiyacımız vardır. Bunun için, verileri analiz eden ve raporlar veya bir gösterge tablosu oluşturan birçok veri analizi ve görselleştirme aracı vardır. Şirketler, veriye dayalı kararlar almak için bu raporları kullanır.

Orkestrasyon: Verilerin bu sistemler aracıllğıyla taşınması, bir tür otomasyonda düzenleme gerektirir. Verileri almak, verileri dönüştürmek, verileri gruplar halinde ve akış süreçlerinde taşımak, ardından bunları bir analitik veri deposuna yüklemek ve ardından içgörü elde etmek için analiz etmek tekrarlanabilir bir iş akışında olmalıdır. Bu sayede büyük verilerimizden sürekli olarak içgörüler elde etmemizi sağlar.

Büyük veri teknolojisi endüstrisi yıllık ortalama yüzde 30 oranında büyüyerek, 2023 yılına kadar yaklaşık 40,6 milyar \$'a ulaşması öngörülmektedir. Günümüzde firmalar büyük veri teknolojisini daha çok 
maliyetleri düşürmek, karar vermeyi geliştirmek, gelecek eğilimleri tahmin etmek ve bu doğrultuda yeni ürünler yaratmak amaciyla kullanmaktadir (Natasha, 2020, s.n.p.).

\section{Sivil Havacılık Sektöründe Büyük Veri Teknolojisi}

Sivil havacılık sektöründe geleneksel olarak verinin büyük ve önemli bir rolü vardır. Süreç yönelimli bir sektör olarak havacılık dünyası, işleri yönlendirirken veri toplama, yorumlama, analiz etme ve veriden gelir elde etmeye dayanır. Sektör paydaşları olan havayolları şirketleri, havalimanları, uçak imalatçıları, tedarikçiler, hükümetler ve diğerleri operasyonel planlama ve yürütme faaliyetlerinde veriye bağımlıdır. Sivil havacılık sektörü, yoğun rekabet altında son derece ince marjlarla faaliyet göstererek yüzde birin altında bir birikimli kâr marjıyla her yıl milyarlarca dolar gelir elde eden zor bir alandır. Söz konusu yoğun rekabet, şirketleri para kazanmak, biriktirmek ve verimliliği artırmak istediklerinde büyük verinin sağladığı avantajlara odaklayarak yenilikçiliğe yol açmaktadır (Çukur, 2020, s.7-8).

Verileri iş kararlarını iyileştirmek için kullanma fikri, özellikle son yıllarda tüm sektörlerde teknoloji kullanımının ilerlemesi ile büyük oranda artan veri miktarı ile ortaya çıkmıştır. Örneğin sivil havacılık sektöründe kullanılan uçaklarda kullanılan her büyük sistemin (motorlar, aviyonikler vb.) sensörler yoluyla izlenmesinden elde edilen verilerin işlenmesi yoluyla, hangi parçaların ne zaman bakıma alınacağı veya değiştirileceği gibi konularda kestirimci bakım modellerinin oluşmasına olanak sağlamaktadır. Bunun yanında daha akıllı ve daha verimli yakıt ikmali kararları vermek için yakıt izleme verileri analiz edilebilir. Hava durumu verileri, farklı uçuş koşullarının motor performansını nasıl etkilediğini belirlemek ve en verimli görev yolunu seçmek için kullanılabilir. Onarım önceliklerini belirlemek için bileşen izleme verileri kullanılabilir. Bu bilgiler, sivil hava yolu işletmecileri için, verimliliği ve müşteri hizmetlerini iyileştirmek için çok önemlidir ve bu nedenle gelirin ve verimliliğin artmasında önemli rol oynayacaktır (Sumathi vd., 2017, s.130).

Sivil hava yolu işletmeleri elde ettikleri devasa büyüklükteki verileri düzenli ve planlı bir şekilde kullanarak ürün ve hizmet kalitesinden ödün 
vermeden maliyetleri düşürürken daha fazla gelir elde etme olanağ1 yakalayabilir. Bu durum şirketlerin kendilerini rakiplerinden farklılaştırmaları için fırsatlardır. Büyük veriden elde edilen iç görüler hem üreticiler hem de havayolu şirketleri için önemli fırsatlar sağlamaktadır.

Günümüzde teknoloji, işletmelerin müşterileriyle bağlantı kurma, işle ilgili kararlar alma ve iş akışları oluşturma şeklini büyük ölçüde değiştirmiştir. Kuşkusuz, sivil havacıllk sektörü de bu değişimden etkilenmiştir. Sektörde bilet satın alma, koltuk seçimi, bagaj, uçağa binme, kara ulaşımı, uçuş öncesi ve sonrası tüm operasyonlarla ilgili çok miktarda dijital veri üretilmekte ve kaydedilmektedir. Artık müşteriler uçuş rezervasyonu için seyahat acentelerine gitmemektedir. Bunun yerine, verilere gerçek zamanlı erişim sayesinde, en iyi fiyat performans analizi yaparak en efektif uçuş rezervasyonunu bireysel olarak yapabilmektedir.

Sivil havacılık sektörü, sürekli genişleyen pazara hizmet etmek için daha iyi araçlar aramaya zorlayan şiddetli bir büyüme yaşamaktadır. Hatta bazı havayolu şirketleri temel iş modellerini değiştirmeyi düşünmektedir. Havacılık sektörü muazzam miktarda veri üretir ve işler. Birçok havayolu şirketi ortaya çıkan muazzam büyüklükteki veriyi yönetecek ve işleyecek altyapıdan yoksundur. Oluşturulacak uygun altyapı ile işlenecek büyük veri, şirketlerin piyasa üzerinde kontrol uygulaması için kullanılabilir (Sumathi vd, 2017, s.129).

Birçok sivil havayolu şirketi değişen tüm koşullar çerçevesinde, geleneksel iş modelleri yoluyla, sürdürülebilir kârlılığ devam ettiremeyeceklerinin farkına varmıştır. Sektördeki şirketler bir dönüm noktasındadır ve mevcut iş modellerinde önemli değişiklikler yapma zorunluluğuyla karşı karşıya kalmışlardır. Bunu değişimin en temel noktası her geçen gün önemi artan büyük veri teknolojisidir. Şekil 2'de büyük veri teknolojisinin havacılık sektöründeki kullanım önceliği açıkça görülmektedir. 


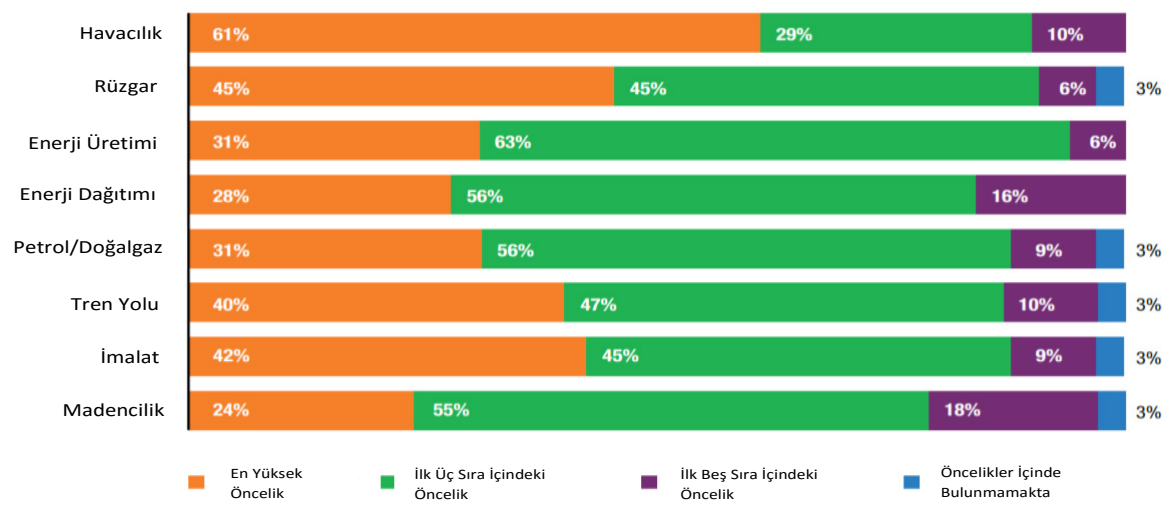

Şekil 2. Endüstri Bazında Büyük Veri Teknolojisinin Öncelikleri (Kaynak: Kelly ve Floyer, 2013)

\section{Büyük Veri Teknolojisinin Sivil Havacılık Sektöründe Kullanım Alan- ları}

Son yıllarda sivil havacılık sektörü, yolcu akışında ve hava trafiğinde artışla sonuçlanan şiddetli bir büyüme yaşadı. Bu ani büyüme, operasyonları yönetmeyi ve yolcu ve kargo güvenliğini sağlamayı beraberinde getirmiştir. Sektörde üretilen verilerin çoğu (yerleşik sensörler, yer istasyonları, uydu sensörleri) sorumlu kişinin bildirildiği bir anormallik bulunmadıkça kullanılmaz. Bu veriler ancak etkili bir bilgi işlem sisteminin varlığında kullanılabilir. Ancak üretilen veri o kadar büyüktür ki geleneksel veri tabanları kullanılarak işlenmesi mümkün değildir. Örneğin ortalama bir Atlantik ötesi uçuşta, yaklaşık 1.000 gigabayt veri üretir. Bu "büyük veriden" faydalı bilgiler çıkarmak, mevcut artan trafik için bile giderleri kontrol altında tutmak, yönetim faaliyetlerini iyileştirmek, güvenliği sağlamak ve gelirleri artırmak için büyük veri teknolojisine ihtiyaç vardır (Sumathi vd., 2017, s.129)

Büyük veri teknolojisi sivil havacılık sektöründe birçok yerde ve aşamada kullanılabilecek durumdadır. Havacılık sektöründe büyük veri teknolojisinin kullanılabileceği alanlar Şekil 3’de tanımlanmıştır. 


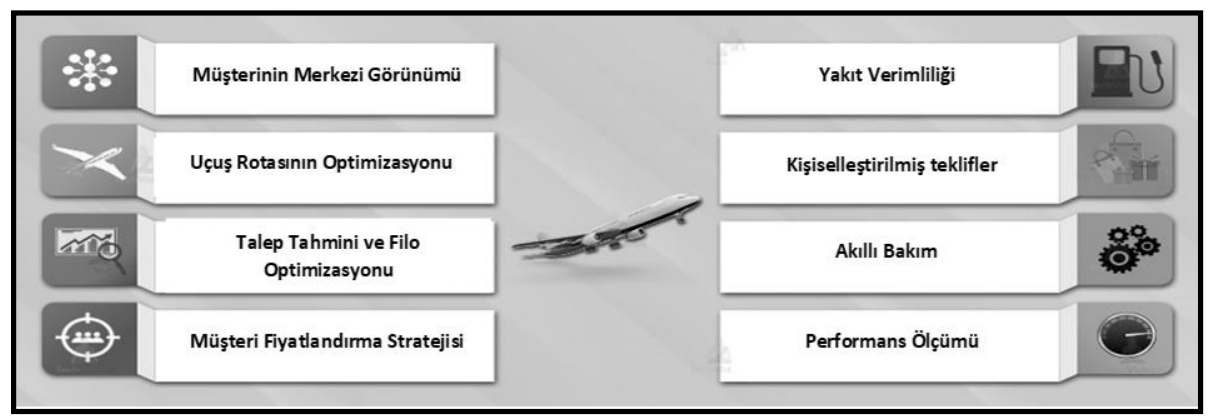

Şekil 3. Sivil Havacılık Sektöründe Büyük Veri Teknolojisinin Kullanım Alanları (Kaynak: https://techvidvan.com/tutorials/big-data-aviation/)

Sivil havacilık sektöründe büyük veri teknolojisi, Şekil 3'de de görüldüğü üzere sekiz farklı alanda kullanılabilmektedir. Bu alanları ve sektördeki işletmelerdeki kullanım şekillerini kısaca açılamak gerekirse (https://techvidvan.com/tutorials/big-data-aviation):

Müşterinin Merkezi Görünümü: Havacılık sektörü, günlük olarak büyük miktarda veri üretir ancak verilerin çoğu organize bir şekilde değildir. Birçok havayolu işletmesinin karşılaştığı en büyük zorluk, veri tabanlarında bulunan müşteri bilgilerinin entegrasyonudur. Örneğin, havayolları şirketlerinin elinde bulunan ve organize biçimde kullanılamayan veriler aşağıdaki şekilde sıralanabilir:

- Bilet rezervasyonu sırasında yapılan online işlemler,

- Web sitelerinden ve uygulamalardan yapılan veri aramaları,

- Müşteri hizmetlerinden alınan veriler,

- Teklifler / İndirimler ve müşteri yanitları,

- Geçmiş seyahat verileri,

Tüm bu veri noktalarını birleştirmek yoluyla, her müşterinin merkezi bir görünümünü oluşturulabilir. Büyük veri teknolojisi, havayolu şirketlerine bu imkânı sağlayan teknolojileri fazlasıyla barındırmaktadır.

Uçuş Rotasının Optimizasyonu: Havacılıkta uçağın satılamayan her koltuğunda bir gelir kaybı vardır. Uçak doluluğunu ve rota kârlılığını belirlemek için rota analizleri yapılır. Havayolları, müşterilerin seyahat davranışlarını analiz ederek, maksimum müşteriye hizmet sağlamak için uçuş rotalarını optimize edebilir. Müşteri potansiyelini artırmak, kapasite 
kullanımını en üst düzeye çıkarmak için çok bu çok önemlidir. Büyük veri teknolojisi sayesinde rota optimizasyonu çok kolay bir şekilde yapabilir ve en kârlı rotalarda uçak sayısı artırılabilir.

Talep Tahmini ve Filo Optimizasyonu: Havayolları müşterilerin geçmiş seyahatlerini analiz ederek, gelecekteki talebi tahmin edebilirler. Tahmine dayalı analitik, gelecekteki talebi tahmin etmede büyük rol oynar. Havayolları, yaklaşan talebi bilirlerse uçak sayısını artırabilir veya azaltabilir. Bu da filo optimizasyonunu artırır ve kapasite kullanımını geliştirir. Mürettebat, müşterileri etkin bir şekilde yönetmek için uygun şekilde tahsis edilebilir. Bu, uçuş operasyonlarındaki dakikliği artıracak ve müşteri memnuniyetini artıracaktır.

Müşteri Fiyatlandırma Stratejisi: Her müşterinin kendine has ihtiyaçları olduğunu bilmek önemlidir. Bazı müşteriler zamana duyarlı olabilirken, bazıları fiyata duyarlı olabilir. Bazı müşteriler olanaklara ve lükse daha fazla önem verirken, bazıları için bu önemli değil. Büyük veri teknolojisi ile müşterilerin birbirinden farklı talepleri analiz edilerek, müşteriler için farklı segmentlere hitap eden çeşitli teklifler oluşturabilir. Teklife bağlı olarak havayolları biletlerini fiyatlandırabilir. $\mathrm{Bu}$ farklı fiyatlandırma stratejisi, her müşteriden maksimum gelir elde edilmesine yardımcı olacaktır.

Yakıt Verimliliği: Havayollarında ortalama yakıt harcaması, operasyonel maliyetlerinin yüzde 23'ünü oluşturmaktadır. $\mathrm{Bu}$ nedenle, hava taşıyıcılarının yakıt maliyetlerini düşürmesi son derece önemlidir. Rüzgâr hızı, nem, sıcaklık, uçak ağırlığı, irtifa, hava yoğunluğu gibi çeşitli dış faktörler bir uçuşun yakıt verimliliğini belirler. Tüm bu veriler, sensörlerden gerçek zamanlı olarak toplanır. Veri Analitiği, uçak için en uygun maliyetli rotayı belirlemek için tüm bu faktörleri analiz edebilir. Dünyanın en büyük motor üreticilerinden olan General Electric' in raporuna göre, jet yakıtındaki yüzde 1'lik bir azalma, havacılık endüstrisinde 30 milyar dolara kadar tasarruf sağlayabilecektir. Büyük veri teknolojisi gerekli olan tüm verileri eş zamanlı olarak toplama ve işleme özelliği ile havacılık sektöründe yakıt verimliliğini en üst düzeye taşıyacak ve büyük oranda yakıt tasarrufu sağlanacaktır. 
Kişiselleştirilmiş Teklifler: Büyük veri analizi müşterilerin seyahat davranışlarını ve ödeme istekliliğini anlamamıza yardımcı olur. Müşterinin tercih ettiği konumu, arama geçmişini analiz ederek, müşteriye yönelik hazırlanmış özelleştirilmiş tekliflerle onları hedefleyebiliriz. Özelleştirilmiş teklifler, her zaman müşterileri çeker ve müşteri memnuniyetini ve bağlılığını artırmaya yardımcı olur.

Akıllı Bakım: Çoğu zaman uçuşlarda gecikmeler ve iptaller görmekteyiz. Çoğu zaman bu durumun arkasındaki ana sebep, teknik aksaklıklar nedeniyle planlanmamış uçak bakımlarıdır. $\mathrm{Bu}$, müşteri memnuniyetsizliğine ve ayrıca uçağın arıza süresinden dolayı gelir kaybına neden olmaktadır. Şaşırtıcı bir şekilde, gecikmelerin \% 30'u plansız bakımdan kaynaklanmaktadır.

Büyük veri teknolojisi bu durumu etkili bir şekilde çözmek için şirketlerin imdadına yetişebilir. Uçağın sağlığını izlemek için kritik yerlere sensörler takılabilir. Tahmine dayalı analitik, acil bakım gerektiren parçanın ve ne zaman değiştirileceğinin belirlenmesine yardımcı olabilir. Büyük Veri Analizi, varlık kullanımına yardımcı olabilir ve böylece havayolunun kârlılığını artırabilir.

Örneğin Boeing, 4000 uçakta günde yaklaşık 2 milyon durumu analiz ettiği bir Uçak Sağlık Yönetim Sistemine sahiptir. Büyük veri teknolojisi, Uçak Sağlık Yönetim Sistemi yardımıyla:

- Mekanik analiz, uçuş içi ölçümler gerçekleştirilir,

- Bakım periyodları ve yerleri etkili bir şekilde planlanabilir,

- Planlanmamış arızaları ve alınması gereken önlemi tahmin edebilir.

Performans Ölçümü: Büyük veri teknolojisi sayesinde, havayolları aşağıdaki gibi çeşitli performans parametrelerini etkili bir şekilde analiz edebilmektedir:

- Yolcu Başına Kâr

- Uçuş Başına Ortalama Gelir

- Uçuş/Sektör Başına Uçulan Yolcu Sayısı

- Ortalama Uçuş Doluluk Oranları

- Çifte Rezervasyon Oranları

- Uçuş Başına İşletme Maliyetleri 
Sivil havacılık sektöründe büyük veri teknolojisinin Şekil 3'de belirtilen kullanım alanları incelendiğinde, müşteri ilişkileri yönetimi ile ilgili alanların bir adım öne çıktığı görülmektedir. Sektördeki hedef müşteri kitlesinin özellikleri ve sunulan hizmetin homojen yapısı dikkate alındığında müşteri odaklı bir pazarlama anlayışının temel alınması esastır. Havayolu firmaları müşteri odaklı bir yapı oluşturabilmek için kişiselleştirilmiş bir müşteri ilişkileri yönetim sistemi kurmalıdır. Kişiselleştirilmiş müşteri ilişkileri yönetim sistemi için her bir müşteri ile ilgili tüm verilerin düzenli bir şekilde toplandığı, depolandığı ve işlendiği büyük veri teknolojisine ihtiyaç vardır. Büyük veri teknolojisi üzerine kurulan ve işletilen bu sistemin detayları Şekil $4^{\prime}$ te gösterilmiştir.

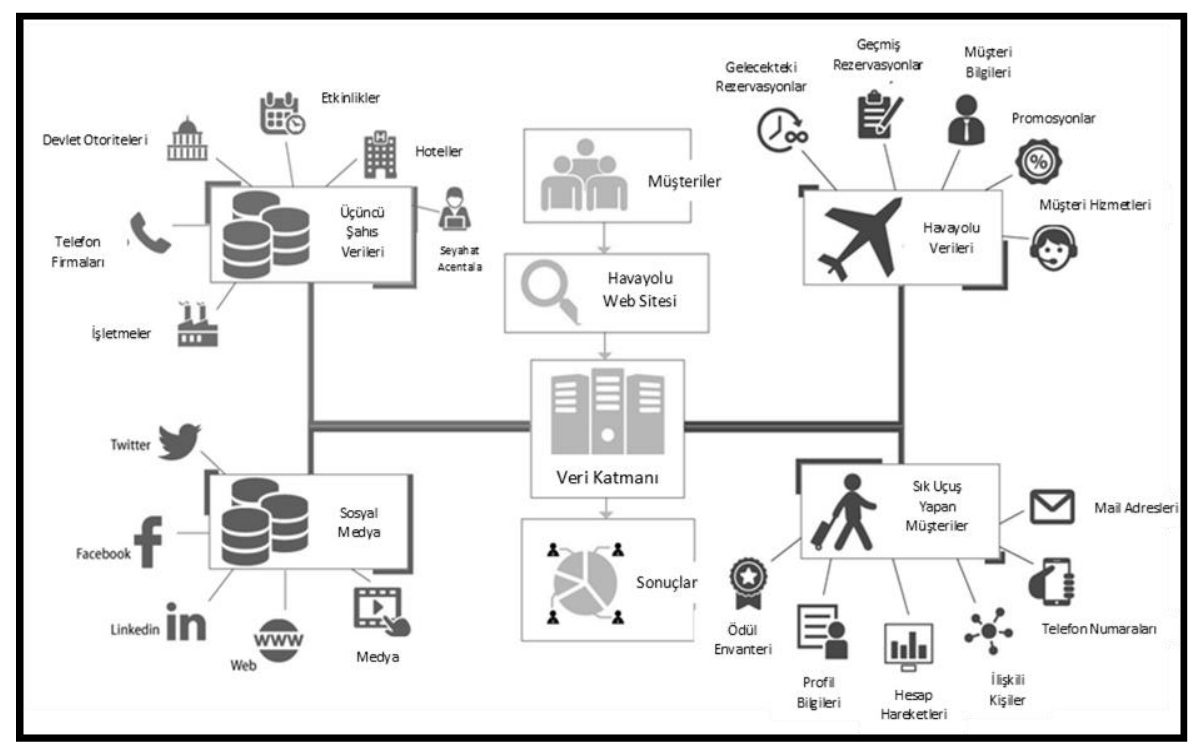

Şekil 4. Sivil Havactlk Sektöründe Büyük Veri Teknolojisi Temelli

Kişiselleştirilmiş Müşteri İlişkileri Yönetim Sistemi (Kaynak: Ross-Smith, n.d.)

Şekil 4 incelendiğinde, havayolu şirketlerinin kişiselleştirilmiş müşteri ilişkileri yönetim sistemi için müşteri ile ilgili birçok farklı kanaldan elde ettiği çok çeşitli verileri depoladığını ve analiz ettiğini görmekteyiz. Büyük veri teknolojisi yardımıyla depolanan, analiz edilen ve kişisel pazarlama stratejilerine dönüştürülen verilerden bazılarına göz atalım;

- Geçmiş rezervasyonlar ve gerçekleştirilen uçuş bilgileri, 
- Gelecekteki rezervasyonlar,

- Ödeme geçmişi ve alışkanlıkları,

- Bagaj teslim bilgileri,

- Kredi kartı puan kullanma alışkanlıkları,

- Araç kiralama ve otel bağlantıları,

- Kişisel bilgiler ve iletişim bilgileri,

- Müşteri hizmetleri birimi görüşme kayıtları,

- Faydalanilan promosyonlar,

- Kazanılan puan, mil vb. ödülleri ve kullanma alışkanlıkları,

- Sik sık beraber seyahat ettiği ilişkili kişilerle ilgili bilgiler,

- Sosyal medya ve internet üzerinden işletme ile ilgili etkileşim bilgileri,

- Müşterinin sosyal medyadaki paylaşımları, etki düzeyi ve etki çevresi,

- Uçuş sırasında veya havayolu mağazalarından yapılan alışverişler,

- Uçuş sırasındaki yiyecek içecek tercihleri,

Yukarıda tanımlanan çeşidi ve detayı arttırılabilecek verilerin tümü büyük veri teknoloji yoluyla sistemli bir şekilde depolanıp analiz edilmektedir. Hava yolu şirketleri müşteriden elde ettikleri bu verileri işleyerek, müşterilerinin istek, deneyim ve ihtiyaçlarını bireysel olarak takip edebilmekte; hemen akabinde ise, iyileştirme stratejileri geliştirebilmektedir.

Günümüzde birçok hava yolu şirketi müşteri ilişkileri yönetiminde büyük veri teknolojisini kullanmaktadır. Örneğin United Havayolları, müşteri profilindeki 150 farklı veriyi analiz edebilen akıllı "veri topla, algıla, harekete geç" sistemini kullanmaktadır. Bu sistem ile; bir önceki satın alımlarından müşteri önceliklendirmeye dek her şey kişiye özel bir teklif sunabilme amacıyla ölçümleniyor. Sistemin yararına gelince; United Havayolları bu sistemi kullanmaya başladığı dönemden itabaren gelirini yıldan yıla yüzde 15'i geçkin bir oranda arttırmıştır. Bir başka örnekte ise, British Havayolları, her müşteriye kişiselleştirilmiş sonuçlar sağlamak için verilerin derinlemesine analizini yapan "Beni Tanı" adını verdiği bir sistemi kullanıyor. Müşterilerini "ilgisiz teklifler için zamanı olmayan meşgul kişiler" olarak tanımlayan British Havayolları, müşteri verisini müşterilerin göz atması için onlara özel ve hedeflenmiş "bir sonraki en iyi 
teklif"e dönüştürüyor (https://www.exastax.com.tr/). Böylece gereksiz pazarlama faaliyetlerinde de tasarruf etmiş oluyor. Bahsedilen bu iki örnekteki sistemlerin temeli büyük veri teknolojisine dayanmaktadır.

Sivil havacilık sektöründe büyük veri teknolojisinin Şekil 4'te belirtilen kullanım alanları incelendiğinde, hava yolu şirketlerinin güvenli uçuş standartlarının sağlanması ve uçuş verimliliği konuların büyük veri teknolojisinden faydalandıkları görülmektedir. Şekil 5'te bu sürecin nasıl yönetildiği detaylı bir şekilde açılanmaktadır.

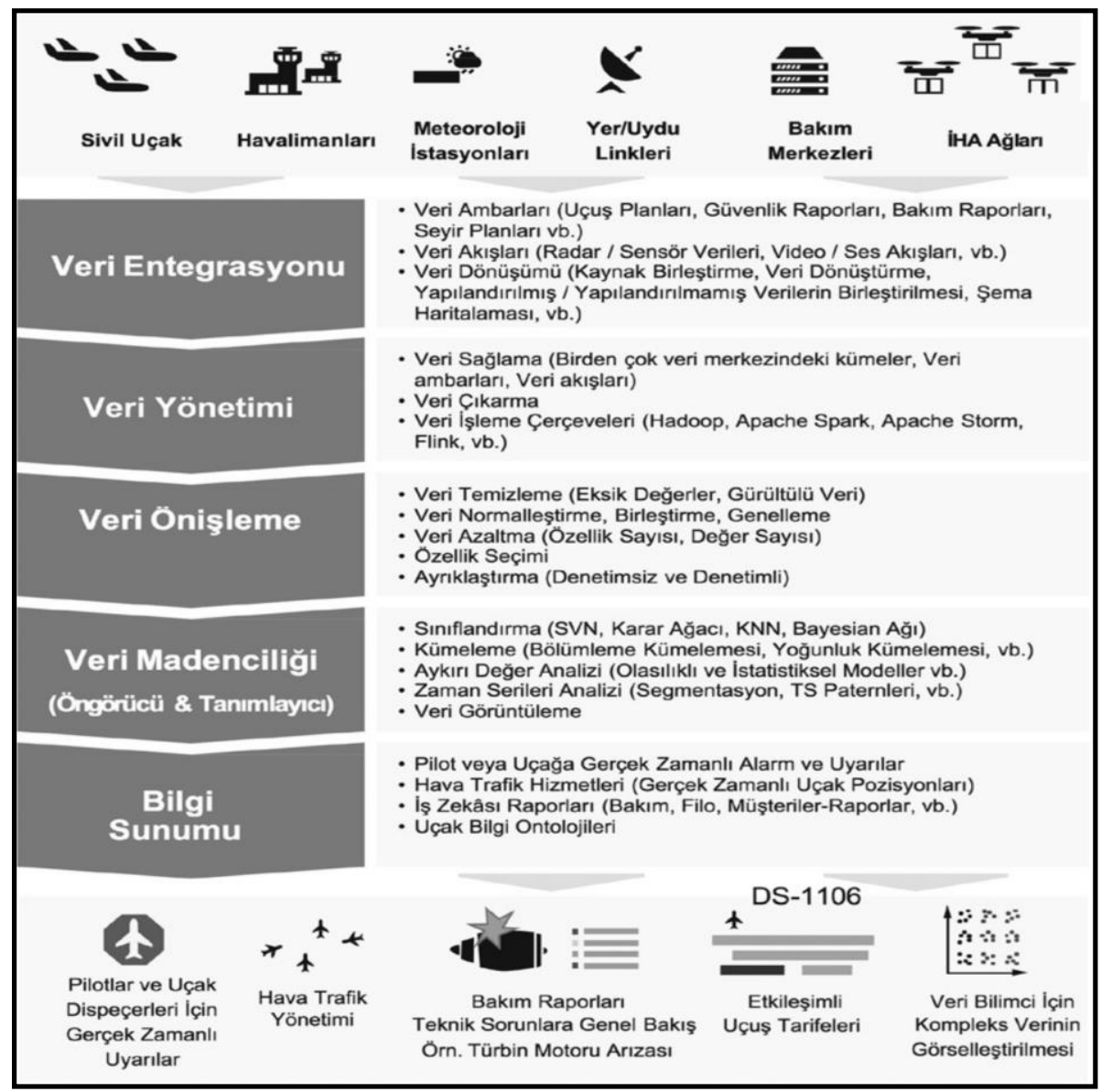

Şekil 5. Sivil Havacıllk Sektöründe Büyük Veri Teknolojisinin Güvenli ve Verimli Uçuş Süreçlerine Katkısı (Kaynak: Çukur, 2020, s.19) 
Şekil 5 incelendiğinde büyük veri teknolojisi altyapısı ile birçok platformdan elde edilen veriler ilk olarak "Veri Entegrasyonu" aşamasında belirlenen prosedürler çerçevesinde sisteme entegre edilmektedir. İkinci aşama olana "Veri Kümeleme" aşamasında sistemde veriler kümelenmekte ve bu süreçte gereksiz görülen veriler süreçten çıkarılmaktadır. Üçüncü aşama olan "Veri Önişleme" aşamasında verilerin birleştirilmesi, temizlenmesi, gereksiz görülenlerin çıkarılması işlemleri gerçekleştirilir. Dördüncü aşama olan "Veri Madenciliği" aşamasında tüm veriler belli teknikler kullanılarak işlenir öngörüler veya eş zamanlı kullanılabilecek bilgiler elde edilir. Beşinci ve son aşama olan "Bilgi Sunumu" aşamasında büyük veri sisteminden elde edilen öngörüler raporlar halinde ilişkili birimlere aktarılır. Örneğin uçağın tüm uçuş takvimindeki faaliyetlerini dikkate alınarak teknik bakım birimleri periyodik veya beklenmedik bakımları konusunda uyarılarak gerekli planlamaların önceden yapılması sağlanabilmektedir. Bunun yanında eş zamanlı kullanılması gereken bilgi ve tespitlerde anlık olarak ilgili birimlere aktarılır. Örneğin pilotlar hava durumu, rota güncelleme önerisi ve uçağın teknik durumu hakkında anlık olarak bu sistem sayesinde bilgilendirilerek; özellikle uçuş güvenliği konusunda önlemlerin gecikmeden alınması ve uçuş verimliliğinin arttırılması sağlanabilmektedir.

Havayolu sektöründe uçuş verimliliğinin en önemli unsuru yakıt maliyetleridir. Yakıt, tüm havayolu işletme maliyetlerinin ortalama yüzde 17 'sini oluşturuyor. Bu maliyet kalemi işçilikten sonraki en önemli genel gider kalemi olarak karşımıza çıkmaktadır. Bu nedenle, yakıt verimliliği kritik bir ölçüdür. Havayolları büyük veri teknolojisi ile yakıt verimliliklerini arttırabilirler. Daha fazla hesaplama gücü, havayollarının yolculuk başına yakıt tüketimini analiz etmelerini sağlayan büyük hacimli verileri toplamasına ve analiz etmesine olanak sağladı. Örneğin Southwest Havayolları, yakıt tüketiminin yanı sıra rüzgar hızı, sıcaklık ve uçak ağırlığını ölçen uçağa yerleştirilmiş sensörlerden veri toplayarak yakıt verimliliğini arttırabilecek öngörüler oluşturan bir sistem kullanmaktadır (Carlato, 2020, s.1).

Bir başka örnekte ise, Boeing, Uçak Sağlık Yönetim sisteminin bir parçası olarak 4.000 uçağında, günde 2 milyon durumu analiz ediyor. Mekanik analiz raporları ve uçuş sırasındaki ölçüm bulgularını içeren bu 
sistem, Boeing'in bakım ve dağıtımı planlamasına yardımcı olur. Bu sistem sayesinde muhtemel hatalar tahmin edilerek önleyici eylemler planlanabilmektedir. Böylece bakım onarım gecikmelerinden veya hatalarından kaynaklanabilecek maliyet kayıpları önlenmiş olacaktır (Carlato, 2020, s.1).

Havacılık sektöründeki düzenleyici kuruluşlarda, büyük veri teknolojisini kullanarak uçuş güvenliğini arttırmaya yönelik uygulamalar yapmaktadır. Avrupa Havacılık Güvenliği Ajansı, uçuş riskini tespit etmek için, uçuş içi telemetri verilerini, hava trafik kontrol bilgilerini ve hava tahminlerini toplayan ve analiz eden Data4Safety programını başlatmıştır. Program, düzenleyicilerin güvenlik risklerini belirlemesine ve paydaşlara tavsiyelerde bulunmasına izin vermektedir. Bu program, büyük veri analitiğini ve hesaplama gücünü birleştirerek havacılık zincirindeki zayıf bağlantıları güçlendirmeyi ve uçuş güvenliğini arttırmayı amaçlamaktadır (Carlato, 2020, s.1).

\section{Sivil Havacılık Sektöründe Büyük Veri Mimarisinin Oluşturulması}

Sivil havacılık sektörü uçuş operasyonları, havaalanı hizmetleri, bakım onarım ve müşteri hizmetleri gibi birçok farklı ve karmaşık unsurun koordineli bir şekilde yönetilmesi gereken bir sektördür. Bu süreçler iyi yönetilmezse bu durum sadece sektörün işletme maliyetlerini önemli ölçüde artırmakla kalmaz, aynı zamanda ciddi havacılık kazalarına da sebep olabilir. Bu nedenle, havacılık sektöründe yönetim performansının nasıl iyileştirileceği, her zaman havayollarının çözmeye çalıştığı önemli sorunlardan biri olmuştur (Dou, 2020, s.3). Uzun yıllar geleneksel yöntemlerle çözülmeye çalışılan yönetim sorunlarında pek başarılı olunduğu söylenemez. Bilişim çağının en önemli çıtılarından olan büyük veri teknolojisi, tüm bu karmaşık süreçlerin koordineli bir şekilde yönetilmesine yardımcı olabilecek bir teknolojidir. Sektörde büyük veri teknolojisinin yönetim sistemi içinde nasıl konumlandırılabileceği Şekil 6'da açıklanmaya çalışılmıştır. 


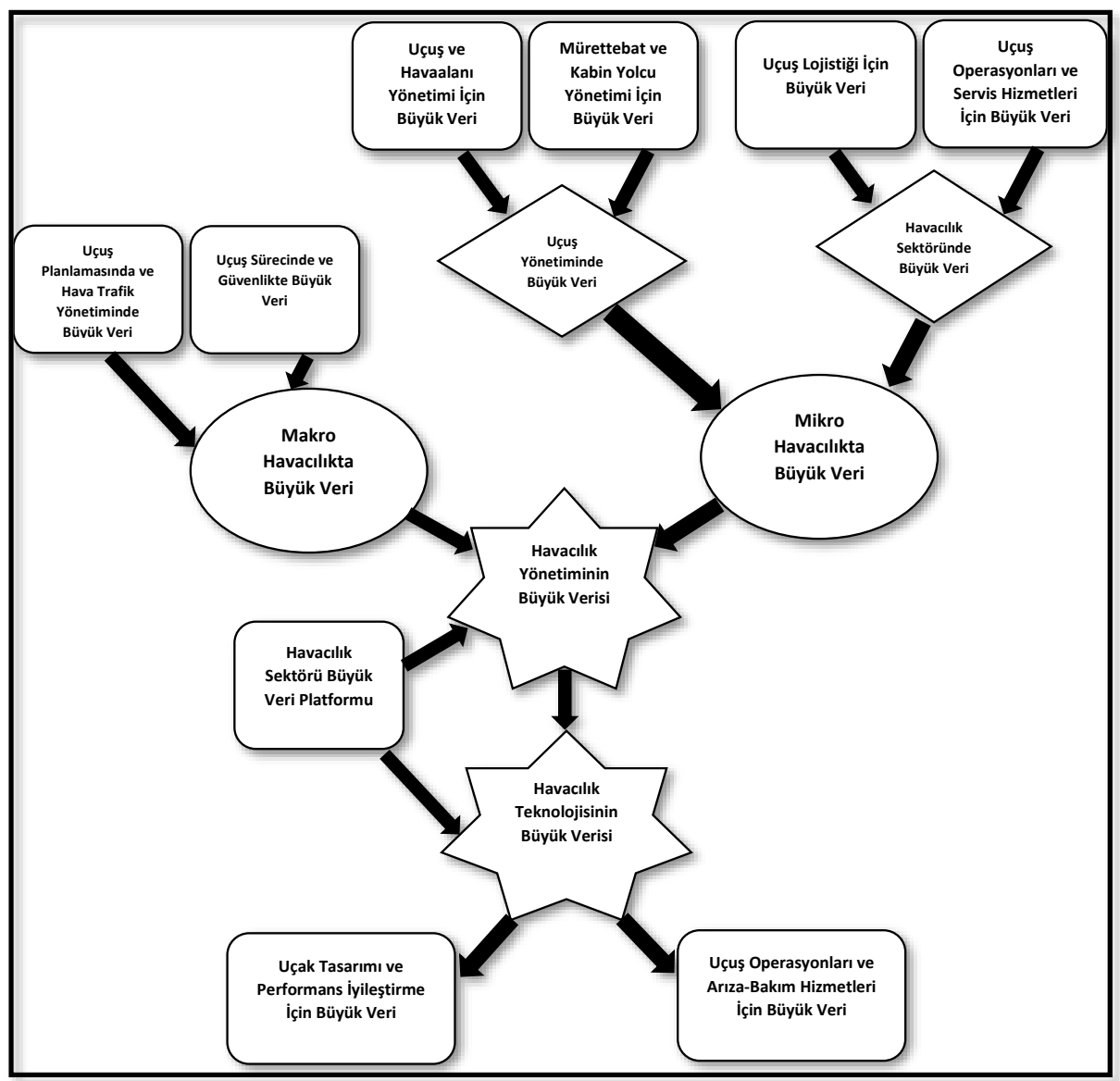

Şekil 6. Sivil Havacılık Sektöründe Büyük Veri Platformu Bilgi Sistemi (Kaynak: Dou, 2020, s.6)

Havacılık sektöründe büyük veri teknolojisi yoluyla öncelikle havacılık operasyonlarının tüm verileri kaydedilir ve elde edilen bu veriler işlenerek anlık veya dönemsel analizler yapılır. Analiz sonuçları öncelikle uçuş güvenliğinin arttırılması için kullanılır ve bununla beraber yönetim performansının optimize edilmesi hedeflenir.

Şekil $6^{\prime}$ da görüldüğü üzere büyük veri teknolojisi makro ve mikro havacılıkta farklı amaçlar doğrultusunda kullanılır. Makro havacılık yönetimi büyük veri teknolojisini uçuş planlamasında, hava trafiğinin 
düzenlenmesinde ve uçuş güvenliğinin sağlanmasında kullanılır. Özellikle son yıllarda uçak sayılarının ve bunun paralelinde uçuş sayılarının artması uçuş güvenlik risklerinin artmasına sebep olmuştur. Büyük veri teknolojisi ile elde edilen verilen anlık analizi yoluyla uçuşların planlı ve daha güvenli bir şekilde yapılması olanağı ortaya çıkabilecektir (Dou, 2020, s.4).

Sektörde büyük veri teknolojisi mikro havacllık yönetiminde, esas olarak uçuş ve havacılık işletme yönetiminin temel durumlarını kaydeder, analiz eder ve yansıtır. Bu sürecin alt kırımlarında uçuş ve havaalanı yönetimi, mürettebat yönetimi, uçuş lojistiği ve uçuş operasyonlarının yönetimi büyük veri teknolojisi ile çok daha verimli hale getirilebilmektedir. Mikro havacılık yönetiminde öncelikli amaç havayolu firmasının verimliliğini arttırmak ve bunun paralelinde uçuş güvenliğini arttırmaktır (Dou, 2020, s.4).

Makro ve mikro havacılık yönetim süreçlerinde büyük veri teknolojisi ile elde edilen veriler ve analiz sonuçları uçak tasarımı, performans iyileştirme ve bakım hizmetlerinin planlanması süreçlerinde kullanılmaktadır. Özetle büyük veri teknolojisi sivil havacilık sektörünün tüm paydaşları tarafından tüm yönetim süreçlerinin iyileştirilmesi amacıyla kullanilabilmektedir.

Sivil havacılık sektöründe faaliyet gösteren havayolu firmaları yönetim süreçlerini iyileştirmek amacıyla büyük veri teknolojisini kullanmak isterlerse Şekil 7'de tanımlanan büyük veri mimarisinin bir benzerini oluşturması gerekmektedir. Mimari bulut teknolojisi temel alınarak oluşturulduğundan, Yazılım Hizmetleri (Saas), Platform Hizmetleri (PaaS) ve Altyapı Hizmetleri (Iaas) olarak tanımlanan üç katmandan oluşmaktadır (Li vd., 2017, s.331). 

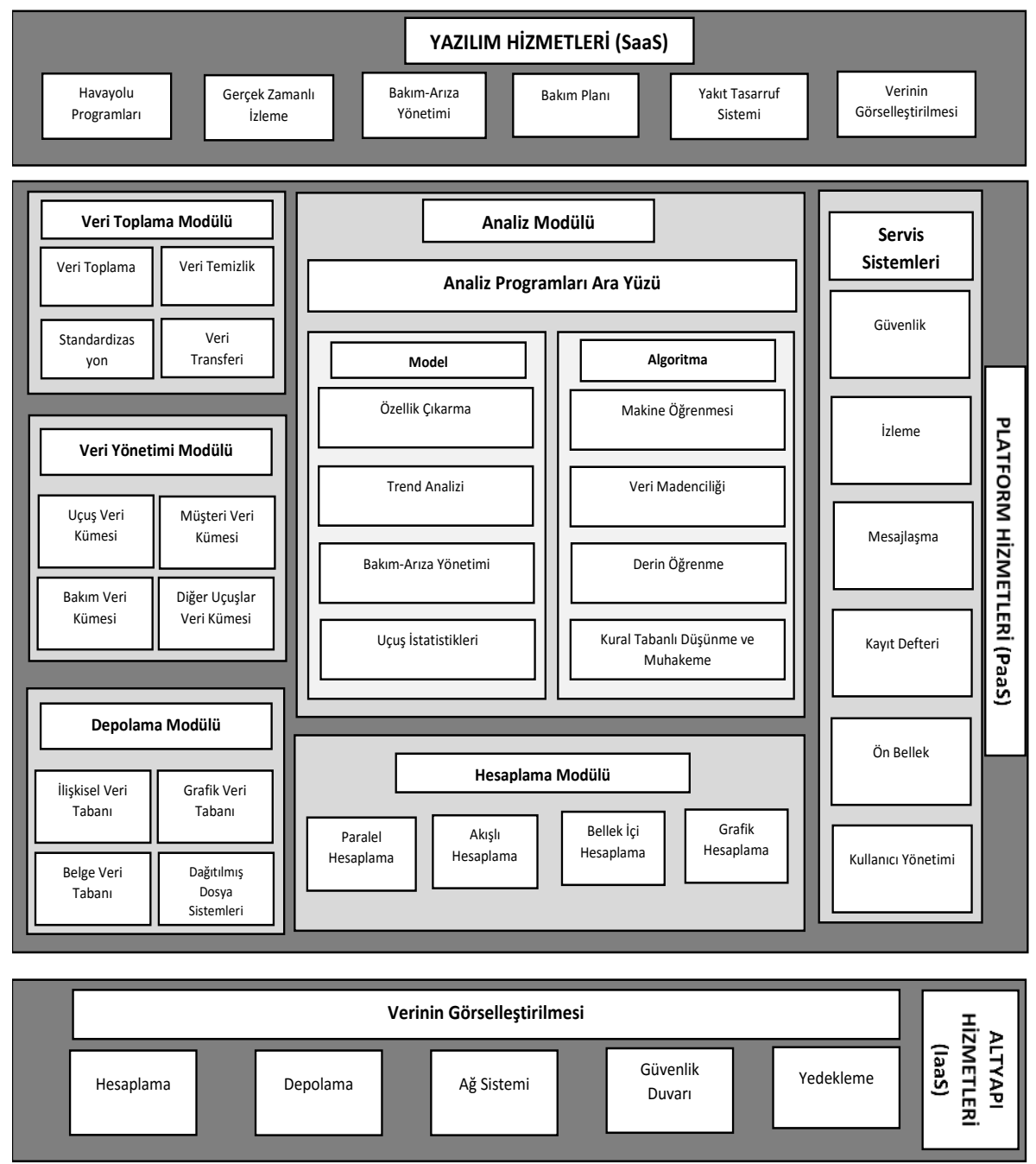

Şekil 7. Sivil Havacılıkta Havayolu Firmalarnda Büyük Veri Mimarisi (Kaynak: Li vd., 2017, s.331)

Şekil 7'de detayları verilen ve üç katmandan oluşan büyük veri mimarisinin her katmanın işlevi aşağıdaki şekilde açıklanmıştır:

Yazılım Hizmetleri (Saas) katmanında, kullanıcılar için gerekli yazılımlar ve uygulamalar bulunmaktadır (Li vd, 2017, s.332): 
- Havayolu Programları: Havayolu programları, hava durumu, alternatif rotalar, yolcu sayısı, bagaj miktarı, personel planlaması ve diğer uçuş takvimleri gibi verileri anlık işleyerek uçuşların gecikmeden yapılmasını sağlayacak en uygun planlamayı hedefleyen yazılımlar barındırmaktadır.

- Gerçek Zamanlı İzleme: Oluşturulan yazılımlar sayesinde, uçakların uçuş sinyallerinin gerçek zamanlı izlenmesi yoluyla plan dışı oluşan durumlarda sistem alarm verir ve en kısa sürede önlem alınması sağlanır.

- Bakım-Arıza Yönetimi: Uçaklarda bulunan gelişmiş algılama teknolojileri sayesinde elde edilen verilerin tahmin yazılımları kullanılarak uçuş güvenliğini en üst düzeyde sağlayacak bakım-arıza yönetim sistemi işletilir.

- Bakım Planı: Arıza tahmin modeli, geçmiş bakım raporları, uzaktan teşhis verileri ve uçuş parametreleri verileri kullanılarak en uygun bakım planları oluşturulur. Tahmin analizi yardımıyla, havayolları rota düzenlemesini doğru bir şekilde ayarlayabilir, planlayabilir.

- Yakıt Tasarruf Sistemi: Yakıt tasarruf sistemi ile, firmalar en az yakıt sarfiyatı ile kârını maksimize edecek en doğru uçuş operasyon planlarını yapıp uygulayabilirler.

-Verilerin Görselleştirilmesi: Büyük veri mimarisi yoluyla elde edilen gerekli gereksiz tüm verilerin analiz edilerek sadeleştirilmesi ve görselleştirilmesi ile, yönetim kademesinin karar alma süreçlerine pozitif katkılar sağlanması hedeflenmektedir.

- Platform Hizmetleri (PaaS) katmanı büyük veri mimarisinin kalbini oluşturmaktadır. Verilerin depolanması, analiz edilmesi ve diğer servis işlemleri gerçekleşmektedir (Li vd., 2017, s.332):

-Veri Toplama Modülü: Verilerin toplandığı, temizlendiği ve standardize edildiği modüldür.

- Veri Yönetimi Modülü: Toplanan verileri, veri kaynaklarına, yani etki alanı veri kümelerine göre farklı veri kümeleri halinde düzenlendiği bölümdür.

-Depolama Modülü: Analiz edilen ve düzenlenen verilerin ilgili veri tabanlarında saklandığı bölümdür.

-Analiz Modülü: Analiz modülünde üç alt bölüm vardır: 
- Model Birimi: Özellik çıkarma, bakım-arıza yönetimi, trend analizi ve uçuş istatistik modellerinin yönetimi.

- Algoritma: Makine öğrenimi, derin öğrenme, veri madenciliği ve kural tabanlı düşünme ve muhakeme alanındaki algoritmaların yönetimi.

- Hesaplama Birimi: Platformun analiz hizmetlerinde kullanilan hesaplama yöntemlerini barındıran bölümdür.

- Servis Hizmetleri Modülü: Güvenlik hizmetleri, izleme, mesajlaşma, kayıt defteri, ön bellek ve kullanıcı yönetimi gibi büyük veri mimarisinin sorunsuz bir şekilde çalışmasını sağlayan alt sistemlerin yer aldığı bölümdür.

Son olarak Altyapı Hizmetleri (Iaas) katmanında ise, hesaplama, depolama, ağ sistemi, güvenlik duvarı ve yedekleme işlemlerinde kullanılan ve büyük veri mimarisini destekleyecek teknik altyapı yer almaktadır. Bu platformda firmanın bilgisayar altyapısı yanında daha çok bulut tabanlı sanal bilgisayar kümeleri kullanılmaktadır (Li vd., 2017, s.332).

\section{Büyük Veri Teknolojisinin Sivil Havacılık Sektöründe Kullanımın Getireceği Muhtemel Avantajlar ve Örnek Uygulamalar}

Literatürde konu ile ilgili yapılan çalışmalar incelendiğinde, büyük veri teknolojisinin kullanımının sivil havacilık firmalarına birçok avantaj getirebileceği belirlenmiştir. Tespit edilen avantajları örnekler yardımıyla aşağıdaki şekilde özetlemek mümkündür (Gough, 2015; Sagina, 2017; Delgado, 2017; Choudhury, 2019; Park, 2019; Carlato, 2020; Natasha, 2020; Wilson, 2020; Zamiatina, n.d.; Dragosavac, n.d.; https://www.exastax.com.tr/):

Gelir Artışı: Büyük veri teknolojisi, müşterileri tercihlerinin firmalar tarafından daha detaylı tespit edilebilmesine yardımcı olur. Örneğin bilet rezervasyonu analizleri, müşterilerin kişiselleştirilmiş tekliflerle hedeflemesine yardımcı olurken, tahmini analiz tekniklerini kullanarak fiyatı gerçek zamanlı olarak optimize edebilmektedir. Sonuç olarak firmalar anlamlı veriler toplayarak belirli bir zaman aralığında daha fazla rezervasyon alarak gelirlerini maksimize edebilirler. 
EasyJet büyük veri teknolojisi ile elde edilmiş verileri analiz eden bir yapay zekâ algoritması ile koltuk fiyatlamasını gerçek zamanlı olarak belirleyebilmektedir. EasyJet bu uygulaması ile koltuk başına ortalama yüzde 20 oranında kârlılık artışı sağlamıştır.

Akıllı Hizmetler: Sivil havacılıkta yönetilmesi en zor ve karmaşık süreçlerden biri bagaj yönetimidir. Büyük veri teknolojisi sayesinde bagajlar artık yolcuların ve firmaların yükü olmaktan çıkarak, herhangi bir güçlük çekmeden özgürce seyahat edilebilmektedir. Örneğin radyo frekansı tanımlamaları ile, bagaj planlaması ve yönetimi sağlıklı bir şekilde yapılarak uçuş güvenliği arttırılır ve bagajlarının hatalı transferi ve teslimi önlenebilir. Bunun yanında yolcular aplikasyonlar yoluyla bagajlarını anlik olarak takip edebilmektedir.

Delta Havayolları, müşterilerin bagajlarını mobil cihazlarından izlemelerine olanak tanıyan bir uygulama kullanmaktadır. Uygulama aslında yalnızca Delta personelinin kullandığı bagaj bilgilerini kullanmasına rağmen 11 milyondan fazla müşteri tarafından indirilip aktif olarak kullanılmaktadır.

Her geçen gün artan havaalanı trafiğiyle birlikte büyük veri teknolojisi, havayollarının özellikle pist bant genişliği, uçak türleri, hava sahası kullanımının optimizasyonu ve uçuş rotalarının tespiti vb. konularda en doğru tercihlerin yapılmasına yardımcı olur.

Maliyet Azaltma: Havayollarında işletme maliyetlerinin ortalama yüzde 17 'sini yakıta harcanmaktadır. Büyük veri teknolojisi yoluyla tüm rota alternatifleri, uçak tipleri, hava durumu, muhtemel uçuş ağırlıkları vb. verileri toplamak ve analiz etmek mümkündür. Analizlerden elde edilen bulgulara dayanarak, bir uçuş için gereken en uygun yakıt miktarı tespit edilir ve uçuş planlamaları buna uygun olarak yapılır. Böylece uçuş maliyetlerinin minimize edilmesi sağlanabilir.

Southwest Havayolları yakıt tüketimi optimizasyonunu sağlamak için büyük veri teknolojisinden faydalanmıştır. Firma 700'den fazla Boeing 737'den oluşan filosunun yakıt tüketimini iyileştirmek için, motor üreticisi "General Electiric Aviation" tarafından geliştirilen Uçuş Analiz Sistemini (Flight Efficiency Services - FES) kullanmak üzere bir sözleşme imzalamıştır. Bulut tabanlı çalışan sistem, bir uçuş sırasında uçak tarafından 
üretilen verilerin toplanmasına ve analiz edilmesine olanak tanır. Örneğin pilotlar, aynı varış noktasına bir sonraki uçuş için gereken yakıt miktarını planlarken rüzgâr hızı, havadaki nem oranı, uçak ağırlığı ve hızı, maksimum itme gücü ve irtifa hakkındaki bilgileri kullanarak analiz yapan bu sistemi kullanarak karar verirler.

General Electiric Uçuş Analiz Sisteminin (FES) Avustralyalı Qantas Havayolları tarafından kullanmaya başlandığını ve mevcut uluslararası müşteriler EVA Havayolları, AirAsia, Swiss Havayolları, Zhejiang Loong Havayolları ve SpiceJet' inde sisteme katılacağını duyurmuştur.

Sektörde bir diğer önemli ve beklenmedik maliyet kalemi bagaj hasarları ve kayıplarıdır. Kural olarak, bagaj hasarları ve kayıpları firmalar tarafından müşterilere ödenir. Büyük veri teknolojisi ile, gerçek zamanlı bagaj takibi yapılabilir ve böylece bagajların kaybolması veya hasar görmesi en aza indirilebilir. Böyle bir sistem firmalara önemli oranda maliyet avantajı sağlayacaktır.

Müşteri Memnuniyeti: Firmalar büyük veri teknolojisi ile elde edilen veriler yardımıyla tahmine dayalı analiz, duyarlılık analizi ve seyahat yolculuğu analizi gibi analizler kullanarak müşteri odaklı bir pazarlama anlayışı oluşturabilmektedir. Müşterilerin ihtiyaçlarına, alışkanlıklarına, zevklerine ve deneyimlerine en uygun özel teklifler sunabilmektedir. Ayrıca bir uçuş gecikmesi veya bagaj kaybı meydana geldiğinde yolcular gerginleşir. Müşteriler bir havayolu temsilcisinden zamanında bir sorunla ilgili yanıt veya açıklama alamazlarsa, büyük olasılıkla bir sonraki seyahatleri için bu havayolunu seçmeyeceklerdir. Müşteri sorularına yanıt verme hızı, bir sorunu çözmek için atılan gerçek adımlar kadar önemlidir.

Southwest Havayolları, müşteri hizmetleri temsilcilerinin kaydedilen her müşteri etkileşiminin detaylarını anlamalarına imkân tanıyan bir konuşma analitiği aracı kullanmaktadır. Ayrıca, gerçek zamanlı olarak müşteriler hakkında daha fazla bilgi almak için sosyal medya gibi çeşitli çevrimiçi kanallardan gelen verileri analiz eden bir veri analitiği sistemi kullanmaktadir.

British Havayolları ise, müşterilere kişiselleştirilmiş arama sonuçları sağlamak için akıllı bir "Beni Tanı" uygulaması kullanmaktadır. Büyük veri teknolojisi tabanlı çalışan bu uygulama, kişisel müşteri hedefli tek- 
lifler oluşturmak için derinlemesine veri analizleri yapar. British Havayolları, bu uygulama ile ilgili şirketin müşterilerin seyahat ihtiyaçlarını anladığı gerçeğini seven müşterilerinden çok sayıda olumlu geri bildirim almıştır.

Sadece havayolu şirketleri değil havaalanı işletmecileri de büyük veri teknolojisini faaliyetlerinde yaygın olarak kullanmaya başlamıştır. Miami International havalimanı, yolcuların deneyimlerini gerçek zamanlı olarak iyileştirmek için yolcuların yolculuklarıyla ilgili bilgi ve destek aldıkları büyük veri teknolojisi tabanlı bir uygulama başlatmıştır.

Dijital Dönüisüm: Sivil havacılık sektörü yolculara yüksek standartlı hizmetler sunabilmek için dijitalleşme alanında büyük yatırımlar yapmaktadır. Günümüzde dijitalleşen hizmetler, müşterilere kişisel çözümler sunmaya odaklanmaktadır. Müşterilerin kişisel ihtiyaçlarının belirlenmesi için büyük veri teknolojisi yoluyla depolanan müşteri ile ilgili geçmiş tüm verilerin analiz edilmesi gerekmektedir. Bu dijital çözümleri müşterilerine en etkin şekilde sunan firmalar sektörde rakiplerinin bir adım önüne geçebilmektedir.

Türk Hava Yolları, İstanbul'un yeni havaalanında Büyük Veri ve Nesnelerin İnterneti teknolojilerini kullanmayı planlamaktadır. Yeni İstanbul Havaalanında, müşterilerin akıllı telefonlarıyla etkileşime geçecek beacon'lar kullanarak müşterileri salonlara, yemek alanlarına, çıkış kapılarına ve istenen konuma doğru yönlendirmeyi amaçlamaktadır. Buna ek olarak müssteriler, otomobillerini park ettikleri yeri ve çocuklarının nerede olduğunu akıllı giyilebilir teknoloji ürünleri aracıllğı ile takip edebilecekler.

Performans Ölçümleri: Havayolları genellikle küresel rekabet ortamında çalışır ve bu nedenle hızlı ve doğru kurumsal performans ölçümleri yapmak zorundadır. Dahası, havayolları hacim odaklı çalışırlar ve yapılacak küçük değişiklikler (harcanan yakıt, taşınan yük, yeni hizmet türleri vb.) olumlu büyük etkiler yaratabilir. Bu nedenle yönetimler zamanında ve uygun eylem planları ile firma performanslarını arttırabilirler. Büyük veri teknolojisi firmalara zamanlama ve uygun eylem planlarının oluşturulması konusunda geçmiş uygulamaların sonuçlarını analiz ederek öngörüler sunabilmektedir. 
Ayrıca firmalar günlük veya haftalık güvenilir performans ölçümleri üretmede önemli zorluklar yaşamaktadır. Büyük veri teknolojisi sayesinde belirli rotalar için günlük veya haftalık tahmini-güncel performans ölçümleri yapılabilmektedir. Bunun yanında uçuş başına uçulan yolcu sayısı, uçulan mesafe, kârlılık, taşınan yük-bagaj, yıpranma vb. konularda performans analizlerinin otomatik hale getirilmesi mümkündür.

Japan Havayolları, yakın zamanda IBM Japonya ile uçak bileşenlerinde sıcaklığı ölçen bir veri toplama sistemi başlatmıştır. Buradaki amaç, toplanan büyük miktardaki verinin analiz edilmesi ile, teknik sorunları tahmin etmek ve maliyetli uçuş iptallerini önlemek için yeterli veri toplamaktır.

Risk Yönetimi: Gerçek şu ki, küresel havayolu endüstrisi geçtiğimiz yıllarda büyük felaketlere maruz kaldı. Bu nedenle, havayollarının kendilerini bu tür olayların olumsuz etkilerinden korumak için çeşitli risk yönetimi modelleri ve stratejileri geliştirmeleri büyük önem taşımaktadır. Büyük veri teknolojisinin gerçekten en çok yardımcı olabileceği yer burasıdır. Uçuş esnasında pilot raporları, olay raporları, kontrol pozisyonları ve uyarı raporları gibi olağanüstü miktarda veri üretilmektedir. Tüm bu verilere akıllıca depolanıp analiz edildiğinde, uçuş güvenliğini anlık olarak arttırmak mümkün olacaktır. Bunun yanında geçmişte yaşanan kazaların tüm verileri toplanarak incelenmesi sonucu muhtemel riskler tespit edilerek gerekli önlemlerin alınması ile uçak kazalarının önlenmesi veya azaltılması mümkündür.

Soutwest Havayolları, olası uçuş güvenliği sorunlarını belirtmek için Amerikan Uzay Ajansı(NASA) ile ortaklık kurmuştur. Bu ortaklık sonucu makine öğrenme algoritmalarını kullanıp, anomaliler hakkında uyarılar vererek potansiyel kazaları önlemek için geniş veri kümelerini hazırlama yeteneğine sahip otomatik bir sistem inşa ederek kullanmaktadır.

Kontrol ve Doğrulama: Havayolu taşıyıcıları, çeşitli operasyonel faaliyetlerinden kaynaklanan maliyetleri kontrol edebilmek için bir dizi kontrol ve doğrulama modeline ihtiyaç duyar. Bunu mümkün kılmak için, havayollarının tüm farklı iş birimlerinden toplanan eksiksiz ve entegre bir uçuş bilgileri veri havuzuna ihtiyacı vardır. Büyük veri teknolojisi ile 
desteklenen veri havuzu, uçak başına gerçek yakıt kullanımı ile planlanmış yakıt kullanımını kıyaslamayı ve mürettebat yönetimi gibi çeşitli verimlilik analizlerinin hesaplanmasını sağlayacaktır. Bunun yanında, her uçuş veya uçakla ilgili tüm verilerin konsolide edilerek analiz edilmesiyle muhtemel teknik sorunların öngörü yoluyla çözümlenmesi sağlanabilir. Böylelikle, her uçuşun veya uçağın 360 derece görünümünün oluşturulması, havayollarının kontrol ve doğrulama sistemlerini önemli ölçüde iyileştirmesine olanak sağlayacaktır.

Qantas Havayolları uzun uçuşlarda pilotların uçuştan önce uyanıklık seviyelerini ve uyku kalitesini takip etmek için pilotlara beyin dalgası monitörleri taktılar. Bunun yanında pilotlardan vücut saatini düzenleyen melatonin seviyelerini ortaya çıarmak için idrar örnekleri alındı. Yorgunluk belirtilerini tespit etmek için uçuş esnasında video kayıtları yapıldı. Böylece pilotların uyanıklık sevileri doğrultusunda uçuş saatleri ve programlarında bireysel düzenlemeler yapılmaya başlandı.

Tahmin Modelleri: Havayolları, mevcut uçak koltuklarının artırılması, ücretlerin ayarlanması, yeni rotaların tanıtılması vb. seçeneklerin etkisini düzenli olarak değerlendirmek için etkili ve bütünsel bir tahmin modelini geliştirmek zorundadır. Büyük veri teknolojisi ile depolanan verilerin analizi yoluyla geliştirilen tahmin modelleri, gerçek istatistiksel eğilim sonuçları da hesaba katılarak son haline getirilmelidir.

United Havayolları her bir müşteri profilinde 150'den fazla değişkeni analiz etmek için, verileri "topla, algıla, harekete geç" isimli bir analiz uygulaması kullanmaktadır. Bu analizler, kişiye özel bir teklif oluşturmak için önceki satın alımlardan müşteri tercihlerine kadar her şeyi ölçer. Topla, tespit et, harekete geç girişimi, United'ın yıllık gelirini ortalama yüzde 15 oranında artırmıştır. Her bir rezervasyonda müşteri çok sayıda veri üretir. Tek bir rezervasyonda bile, müşteriler hakkında birçok bilgi sağlayabilir. Her müşteri profili, geçmiş seyahat detayları, arama geçmişi, indirimlere / tekliflere yanıt, vb. 150'den fazla değişkenden oluşur. United Havayolları bu değişkenleri sadece birkaç saniye içinde analiz eder ve müşterilerine büyüleyici teklifler sunar.

Bakım-Onarım Faaliyetlerinin Planlanması: Sivil havacılık sektöründe uçuş güvenliği kazalarda yaşanabilecek trajik sonuçlardan dolayı çok 
önemlidir. Bu sebeple uçakların bakım ve onarım işlemlerinin titizlikle ve aksatılmadan yapılması muhtemel uçak kazalarının önlenmesi için bir zorunluluktur. Uçakların planlı bakımlarının dışında beklenmedik arızalarının önceden öngörülmesi veya risklerin tespiti için uçuşlarla ilgili tüm verilerin (toplam uçuş saati, hava durumu verileri, uçak sensörlerinden elde edilen veriler, uçuş sırasında yaşanan türbülanslar ve benzeri hava olayları) büyük veri teknolojisi yoluyla toplanması ve analiz edilmesi gerekmektedir. Böylece muhtemel arızaların önceden tespiti ve bakım onarım faaliyetlerin organize edilmesi uçak kazalarının önlenmesinde büyük katkılar sağlayacaktır.

ABD'li havayolu Delta Havayolları, Airbus A320 ve A330 uçakları için operasyonları ve performans verilerini izlemek, analiz etmek, uçak parçalarının arıza olasılıklarını değerlendirmek ve bir sorun oluşmadan önce bakım görevlerini programlamak için Skywise isimli bir uygulama kullanmaktadır. Skywise Airbus tarafından 2017 yılında Palantir Technologies işbirliği ile geliştirilen bir havacılık veri platformu. Skywise, iş emirleri, bileşen verileri, yedek parça envanterleri, uçak ve filo konfigürasyonları, uçakta yerleşik sensör verileri ve uçuş programları gibi sektördeki farklı kaynaklardan gelen verileri bir araya getirmek ve tüm bunları basit bir kullanıcı ara yüzünde sunmak için tasarlanmıştır.

ABD'li teknoloji şirketi SparkCognition, tahmine dayalı bakım ve sorun giderme konusunda Boeing ve ABD Hava Kuvvetleri için benzer bir sistem kurmayı hedeflemektedir. SparkCognition'ın yapay zekası, elde edilen tüm verileri analiz ederek uçak arızaları meydana gelmeden önce uyarmayı amaçlamaktadır. Bunun yanında arıza kodlarını otomatik olarak sınıflandırarak ve en iyi düzeltici eylemleri önererek sorun giderme süresini azaltmayı da hedeflemektedir.

COVIT-19 Pandemisi Sonrasi Yeni Normale Adaptasyon: 2019 yılında başlayan ve çok kısa sürede tüm dünyayı etkisi altına alan COVIT-19 pandemisi birçok sektörü olumsuz etkilemiştir. Olumsuz etkilenen sektörlerin başında havayolu sektörüdür. Bu süreçte birçok havayolu firmasında uçuşlar neredeyse durdurma noktasına gelmiştir. 2021 yılı itibariyle aşılama çalışmalarının hızlanması ile özellikle uluslararası uçuşların kademeli olarak başladığı görülmektedir. Fakat "Yeni Normal” 
olarak tanımlanan bu süreçte havayolu sektörünün yeniden organize olması şarttır. Büyük veri teknolojisi bu yeniden organize olma çalışmalarına en büyük katkıyı sağlayabilecek teknolojisidir. COVIT-19 pandemisi sonrası süreçte havacılık sektöründe büyük veri teknolojisi aşağıda belirtilen alanlarda kullanılabilir:

-Küresel pandemik ilerlemeyi ve iyileşmeyi izleme,

- Bölgesel ve alt bölgesel iyileşmeyi izleme,

- Aşılama süreçlerinin ve aşı karnelerinin takibi,

- Havayolu faaliyetler süreçlerinin yeniden tanımlanması,

-Küresel ve yerel hava yolculuğu talebinin takibi,

- Müşteriye özel hava yolculuğu taleplerinin takibi.

\section{Sonuç}

Günümüz dünyasında bilgi teknolojilerinin gelişmesi ve yaygınlaşması ile, her alanda çok büyük miktarda verinin ortaya çıtığı görülmektedir. Ortaya çıan bu verilerin çoğu değersiz görülerek kaydedilmemektedir. Kalan kısım veriler ise, çoğu zaman kontrolsüz bir biçimde çeşitli platformlara karmaşık bir yapıda kaydedilmektedir.

Büyük veri teknolojisinin ortaya çıkması ve bu teknolojiyi destekleyen bulut sistemleri, yapay zekâ algoritmaları, makine - derin öğrenme sistemleri, veri madenciliği gibi yardımcı teknolojilerdeki gelişmeler, büyük miktarlardaki verileri düzenli bir şekilde depolamayı ve gerektiğinde kullanmayı daha kolay hale getirmiştir.

Sivil havacılık sektörü teknolojik altyapısı sayesinde çok büyük miktarda veri üretme kapasitesine sahiptir. Ancak geçmişte birçok havayolu şirketi üretilen bu verilerden tam olarak yararlanamamıştır. Büyük veri teknolojisi sayesinde sivil havacıllk sektörü, bu muazzam büyüklükteki veri rezervini kullanarak iş süreçlerini yenileyebilir. Örneğin büyük veri teknolojisine dayalı olarak çeşitli tahmin algoritmaları veya derin öğrenme yöntemleri kullanılarak uçuş risklerini azaltmak, pazardaki değişimleri tahmin etmek, maliyetleri azaltmak, uçuş operasyonlarını ve bakım-onarım faaliyetlerini planlamak daha kolay hale gelecektir. Ayrıca büyük veri teknolojisi ve diğer alt teknolojiler yardımıyla, müşteri deneyimleri takip ederek bireysel pazarlama faaliyetleri organize edilebilir. Geleceğin havayolları, hem içeriden hem de 
dışarıdan büyük miktarlarda veri toplama ve işleme becerileriyle kendilerini rekabette pozitif ayrışarak pazardan daha büyük pay alabilecektir.

Büyük veri teknolojisinin önemini anlayan Türk Havayolları, Delta Havayolları, United Havayolları, Qantas Havayolları, Soutwest Havayolları, Japan Havayolları, British Havayolları, EasyJet gibi büyük havayolları ve General Motor, Airbus, Boeing gibi tedarik sağlayıcılar büyük veri teknolojisini farklı uygulama alanlarında kullanmaya başlamıştır. Zamanla büyük veri teknolojisinin kullanım alanlarının çeşitlenmesi kaçınılmazdır.

Tüm dünyayı etkileyen COVIT-19 pandemisi döneminde seyahat kısıtlamaları sebebiyle dünyada faaliyet gösteren havayolları şirketlerinin neredeyse tamamı, eşi görülmemiş bir mali krizle karşı karşıya kalmıştır. Bu süreçte krize sebep olan temel faktörler, düşük kapasite kullanımı, yüksek işçilik maliyetleri, giderek artan petrol fiyatları, düşük müşteri memnuniyeti ve yüksek işletme maliyetleridir. Havayollarının pandemi öncesi var olan, düşük kâr oranları, fiyat rekabeti, artan güvenlik maliyetleri ve hava yolculuğu tüketici davranışındaki sık ve dinamik değişimler gibi sorunları da krizin derinleşmesine etkide bulunmuştur.

Büyük veri teknolojisi yoluyla elde edilebilecek dinamik veri analizleri sayesinde, havayolları küresel ve ülke bazlı talepleri karşılayabilmek için, en uygun uçuş operasyonlarını planlayabilir. Fakat buradaki en önemli nokta, COVID-19 pandemisinden tüm ülkeler eşit düzeyde etkilenmedi. Bu sebeple büyük veri sistemlerinin esnek kurgulanmasi; her ülke veya uçuş rotası için farklı içgörülerin elde edilmesi gerekmektedir. Büyük veri teknolojisi sivil havacılık sektörünün bu belirsiz süreçten en az hasarla çıkmasına yardımcı olacak bir teknolojidir.

Çalışmada büyük veri teknolojisinin sivil havacılık sektöründe kullanım alanları, sektörde faaliyet gösteren firmalara sağlayabileceği fırsatlar örnek uygulamalar ve süreç tanımlamaları yoluyla detaylı bir şekilde açıklanmıştır. Bu çalışmanın sektörde konu ile ilgili farkındalık yaratması ve bundan sonra yapılacak bilimsel çalışmalara katkı sağlaması beklenmektedir. 


\title{
EXTENDED ABSTRACT \\ Use of Big Data Technology and Oncoming New Opportunities in the Civil Aviation Sector
}

\author{
* \\ Erdal Dursun \\ Nisantasi University
}

The massive growth in civil aviation demand over the last fifty years, coupled with the rapid advancement of technology, has emphasized the need for more effective management methods in a sector where security is of paramount importance. These days, fierce rivalry and poor profitability rates will be key defining elements in civil aviation. Large fixed capital investments have arisen in response to these demands, which has resulted in a high degree of technical infrastructure. Large airline companies have created an uncompetitive environment in the sector, as have excessive government subsidies, seasonal fluctuations, and the recent COVID19 Pandemic. All of these factors have combined to create major issues for the industry. New inquiries have surfaced in an effort to make improvements to the industry. These researches are focused on how big data technologies may be used in the industry.

When we talk about big data, we're talking about datasets that can be examined on a computer to find patterns or trends. A dynamic data set is what the concept of big data technology means; it takes all the data in a certain industry and converts it into a form suitable for analysis according to the demands. When it comes to its technical infrastructure, the civil aviation sector generates a lot of data.

Pre-flight, in-flight, and post-flight procedures create and capture enormous amounts of data every day in civil aviation. On a typical civilian trip nowadays, for example, more than 1,000 Gigabytes of data are generated. It is important to gather and analyze this data on a regular basis in order to turn it into meaningful management knowledge. Airlines make use of big data technologies for these objectives. Many tasks that a person cannot perform are made possible thanks to this technology. Large volumes of data can be processed and stored fast thanks to computer algorithms. With the use of analytics, you can make your airline's operations 
even more efficient. With big data technologies, an airline may discover a personalized approach to each passenger and execute marketing programs that promote consumer loyalty. Gathering real-time weather data can also aid in improving flight safety and creating models to anticipate future aircraft problems.

To conclude, big data technology may provide more effective solutions for civil aviation enterprises in areas such as customer satisfaction, cost management, budget management, marketing management, fleet management, maintenance and repair management, and risk management, among others.

The study's goal is to demonstrate the benefits of big data technologies in the civil aviation industry via real-world examples. Additionally, it aims to find new business possibilities for firms in the industry by utilizing big data technologies, as well as to increase awareness about these potential.

As information technology advances and spreads throughout the world, a massive amount of data is being generated in virtually every sector. As a result, most of this new information is discarded as being of little use. The remainder of the data is stored in an unwieldy, disjointed manner across many platforms.

The rise of big data technology, along with advances in supporting technologies including cloud systems, artificial intelligence algorithms, machine deep learning systems, and data mining, have made it simpler to store and utilize enormous volumes of data on a daily basis.

With its technical infrastructure, civil aviation may create enormous volumes of data. There were times in the past, however, when airline corporations were unable to properly utilize these data to their advantage. The civil aviation sector may take use of this vast data resource by implementing new business procedures based on big data technologies. It will be simpler to decrease flight risks, predict market changes, and cut expenses by utilizing various forecasting algorithms or deep learning approaches based on big data technologies, for example. The use of big data and other sub-technologies can also assist plan individual marketing operations based on the experiences of customers. Using their capacity to gather and analyze massive quantities of data both internally and internationally, future airlines will be able to capture a bigger part of the market. 
Because of this, major airlines and suppliers have begun to employ big data technology in a variety of ways. Instances include Turkish Airlines, Delta Airlines, United Airlines, Qantas Airlines, Southwest Airlines, Japan Airlines, British Airways, Easy-Jet and supply providers such as; General Motor, Airbus, Boeing have begun to utilize from the big data technology in different fields. Obviously, as time passes, the applications of big data technologies will broaden.

Travel limitations imposed by the COVID19 epidemic, which spread around the world, forced nearly all airline firms to experience a financial crisis never before seen. Several things are contributing to the problem in this process: a lack of demand, excessive labor expenses, an increase in the cost of crude oil, and low customer satisfaction. Prior to the outbreak of the pandemic, airlines had challenges such as poor profit margins, pricing competition, rising security expenses, and frequent and dynamic shifts in traveler behavior. All of these factors complicated the problem.

Airlines can manage the most effective flight operations to satisfy global and country-based demand utilizing dynamic data analysis made possible by big data technologies. However, the most essential thing to remember is that the COVID19 pandemic has not hit all nations equally. As a result, big data platforms must be built in a flexible manner so that various insights may be obtained for different countries or flight routes. As a result of the development of big data technologies, the civil aviation sector will be better able to weather the current storm and emerge unscathed.

The research elaborates how civil aviation firms may use big data technology and the opportunities it can bring through examples of applications and process definitions. According to the researchers, this study will help spread knowledge about the issue in the industry and inform future research projects.

\section{Kaynakça / References}

Aktan, E. (2018). Büyük veri: Uygulama alanları, analitiği ve güvenlik boyutu. Bilgi Yönetimi, 1(1), 1-22. https://doi.org/10.33721/by.403010.

Carlota F. (2020). Big Data case study: 5 relevant examples from the airline industry. 15 Şubat 2021 tarihinde, https://blog.datumize.com/5-relevant- 
examples-of-a-big-data-case-study-from-the-airline-industry, adresinden erişildi.

Choudhury, A. (2019). 5 Ways data analytics is transforming the aviation industry. 10 Şubat 2021 tarihinde, https://analyticsindiamag.com/5-waysdata-analytics-is-transforming-the-aviation-industry/, adresinden erişildi.

Çukur, F.T. (2020). Sivil havacılıkta büyük veri teknolojisi ve uygulamaları, STM Teknolojik Düşünme Merkezi Araştırma Raporu. 9 Ocak 2021 tarihinde, $\quad$ https://thinktech.stm.com.tr/uploads/raporlar/pdf/21202091831971 stm sivil havacilikta buyuk veri.pdf, adresinden erişildi.

Delgado, R. (2017). How big data helps today's airlines operate. 9 Ocak 2021 tarihinde, https://www.kdnuggets.com/2017/04/big-data-airlines-operate.html, adresinden erişildi.

Dou, X. (2020). Big data and smart aviation information management system, Cogent Business \& Management. 7(1), 1-14. https://doi.org/10.1080/23311975.2020.1766736

Dragosavac, G. (n.d.). Big data analytics airlines. 9 Ocak 2021 tarihinde, http://www.bigdatanalysis.com/big-data-analytics-airlines/, adresinden erişildi.

Gough, T. (2015). How Big data and the industrial internet can help southwest save \$100 million on fuel. 16 Ocak 2021 tarihinde, https://www.ge.com/news/reports/big-data-industrial-internet-can-helpsouthwest-save-100-million-fuel, adresinden erişildi.

Havayolu Sektörü Büyük Veriden Nasıl Yararlanıyor? 16 Ocak 2021 tarihinde, https://www.exastax.com.tr/buyuk-veri/havayolu-sektoru-buyuk-veridennasil-yararlaniyorl, adresinden erişildi.

Kelly, J. ve Floyer, D. (2013). The industrial internet and big data analytics: Opportunities and challenges. 9 Ocak 2021 tarihinde, http://wikibon.org/wiki/v/The Industrial Internet and Big Data Analytics: Opportunities and Challenges, adresinden erişildi.

K1lıç, T. (2018). Big Data Kaç Gigabyte? 9 Ocak 2021 tarihinde, https://medium.com/deep-learning-turkiye/big-data-ka\%C3\%A7-gigabyted664cb78d582, adresinden erişildi.

Li, S., Yang, Y., Yang, L., Su, H., Zhang, G. ve Wang, J. (2017). Civil aircraft big data platform. In 2017 IEEE 11th International Conference on Semantic Computing (ICSC), 328-333. https://doi.org/10.1109/ICSC.2017.51. 
Natasha, (2020). Big data analytics: The solution for Covid-19 airline recovery. 12 Ocak 2021 tarihinde, https://www.iunera.com/kraken/big-data-scienceapps/big-data-analytics-tracking-solution-help-covid-19-airline-recovery/, adresinden erişildi.

Odarchenko, R., Hassan, Z. ve Zaman, A. (2019). Use of big data in aviation: new opportunities, use cases, and solutions. In Automated Systems in the Aviation and Aerospace Industries IGI Global. 436-452. 12 Ocak 2021 tarihinde, https://www.igi-global.com/chapter/use-of-big-data-in-aviation/223739, adresinden erişildi.

Park, E. (2019). The role of satisfaction on customer reuse to airline services: An application of Big Data approaches. Journal of Retailing and Consumer Services, 47, 370-374. https://doi.org/10.1016/j.jretconser.2019.01.004.

Ross-Smith, M. (n.d.). How big data is changing the way we fly. 12 Ocak 2021 tarihinde, https://www.traveldatadaily.com/how-big-data-is-changing-theway-we-fly/, adresinden erişildi.

Sagina, I.J. (2017). Big Data in aviation - Six trending Technologies. 12 Ocak 2021 tarihinde, https://bigdata-madesimple.com/big-data-in-aviation-sixtrending-technologies/, adresinden erişildi.

Sky is the limit for Big Data analytics in the aviation industry. 12 Ocak 2021 tarihinde, https://techvidvan.com/tutorials/big-data-aviation/, adresinden erişildi.

Sumathi, N., Gokulakrishnan, S., Kaushik Ramana, S., Muralitharan, R. ve Kamal, Ch.V.S (2017). Application of Big Data Systems to Airline. Management International Journal of Latest Technology in Engineering, Management \& Applied Science (IJLTEMAS), VI(XII), 129-132.

Wilson, R. (2020). Pick a number: Big data, artificial intelligence and aviation. 10 Ocak 2021 tarihinde, https://www.flightsafetyaustralia.com/2020/05/pick-a-number-big-data-artificial-intelligence-and-aviation/, adresinden erişildi.

What is Big Data - A complete comprehensive guide. 19 Ocak 2021 tarihinde, https://techvidvan.com/tutorials/big-data-complete-guidel, adresinden erişildi.

Zamiatina, A. (n.d.). 9 incredible ways data analytics is transforming airlines. 19 Ocak 2021 tarihinde, https://blog.datumize.com/9-incredible-waysdata-analytics-is-transforming-airlines, adresinden erişildi. 


\section{Kaynakça Bilgisi / Citation Information}

Dursun, E. (2021). Sivil havacılık sektöründe Büyük Veri Teknolojisinin kullanımı ve getireceği yeni firsatlar. OPUS-Uluslararası Toplum Araştırmaları Dergisi, 18(43), 7183-7219. DOI: 10.26466/opus. 936145. 